\title{
Target Anatomic Site Laterality Code
}

National Cancer Institute

\section{Source}

National Cancer Institute. Target Anatomic Site Laterality Code. NCI Thesaurus. Code C93692.

A coded value specifying the side of the body (or a paired org an) that is a target site for an activity or entity. 